\title{
The Role of B-Mannanase (Hemicell) in Improving Poultry Productivity, Health and Environment
}

\section{-Author(s)}

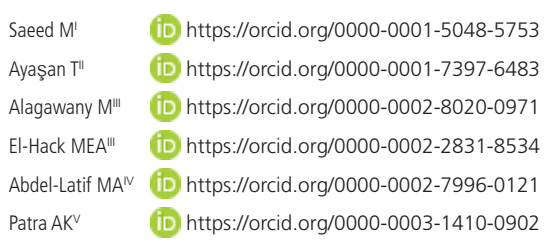

Department of Poultry Science, Cholistan University of Veterinary and Animal Sciences Bahawalpur 63100, Pakistan.

" Osmaniye Korkut Ata University, Kadirli Applied Science School, Department of Organic Farming Business Management, Osmaniye/Turkey.

III Department of Poultry, Faculty of Agriculture, Zagazig University, Zagazig, 44511, Egypt.

iv Department of Nutrition and Clinical Nutrition, Faculty of Veterinary Medicine, Damanhour University, Damanhour 22516, Egypt.

Department of Animal Nutrition, West Bengal University of Animal and Fishery Sciences, Kolkata, India.

\section{Mail Address}

Corresponding author e-mail address Muhammad Saeed

Department of Animal Nutrition, Cholistan University of Veterinary and Animal

Sciences Bahawalpur 63100, Pakistan

Phone: +923400572648

Email: drsaeed89@cuvas.edu.pk

\section{ABSTRACT}

The poultry nutritionists constantly attempt to identify and alleviate the factors responsible for adverse effects on nutrient utilization and production performance in avian species, which are necessary for successful productivity of poultry. Enhanced feed utilization can reduce levels of some nutrients in the diet with concomitant mitigation in nutrient excretion into the environment, reduction of eutrophication and acidification potentials of excreta. Commercial enzymes have been used to improve feed efficiency and utilization in poultry. Among many anti-nutritional factors, the existence of B-mannans in poultry feed ingredients including soybean and other leguminous seeds has been associated with negative effects on nutrient digestibility and high intestinal viscosity that adversely affects innate immunity and microbial proliferation in poultry gut. The B-mannanase (a commercial product named as Hemicell) can hydrolyze B-mannan, an anti-nutritional fiber present in many poultry feed ingredients. Supplement of $B$-mannanase to B-mannan-rich diets may boost the population of intestinal beneficial bacteria, increase the digestibility of mannans, enhance the immunity, suppresses the growth of harmful intestinal bacteria, enhance the digestion and absorption of nutrients in intestinal tracts and reduce the environmental pollution due to poultry excreta. Supplementation of $\beta$-mannanase at the level of 200 and $400 \mathrm{mg} / \mathrm{kg}$ in poultry diets has positively improved blood glucose and anabolic hormone homeostasis, $F C R$, digestible energy, and digestible amino acids. This review describes the promising beneficial effects of $\beta$-mannanase, which may be used in the poultry feed industry for economic benefits. Another objective of this review is to explore the underlying mechanisms of $B$-mannanase that can influence growth, digestion coefficients of nutrients, health and metabolism of nutrients in poultry birds and also the knowledge regarding the useful application of this feed enzyme in the commercial poultry feed industry.

\section{INTRODUCTION}

It is imperative to identify factors that inhibit the digestibility of nutrients for successful commercial poultry production. The non-starch polysaccharides (NSP) like substances of hemicellulose, cellulose, and pectin can reduce nutrient digestibility in poultry (Choct, 1999). Among the NSP, $\beta$-mannans are a group of hemicelluloses, which are present in many ingredients used for poultry feeds like soybean and other leguminous seeds. It occurs in the forms of galactomannans and glucomannans in the cell walls of the plant. The $\beta$-mannan is found in many feedstuffs including palm kernel meal, soybean meal, copra meal, and sesame meal and other leguminous feeds (Dierick, 1989). The soybean meal and full-fat soybean as protein sources are 
most important feed ingredients in poultry diets, and $\beta$-mannan is present in most of the poultry feed. On the other hand, $\beta$-mannan was found to have harmful impacts on performance and health of the animal, compromising feed conversion and weight gain (Anderson \& Warnick, 1964), as well as water and glucose absorption (Rainbird et al., 1984) and insulin secretion (Sambrook \& Rainbird, 1985). The negative impacts of B- mannans on poultry performance were attributed to low digestibility of nutrients and high intestinal viscosity that adversely affects the immune response and microbial proliferation in the gut as well as growth and carcass traits. To solve this problem, some exogenous enzymes such as protease, phytase, avizyme, $\beta$-mannanase and $\beta$-gluconase could be added to poultry diets to help in the digestion of fibers and to decline their negative impact on poultry productivity and health (Alagawany et al., 2015, 2017). In an early study, Patel \& McGinnis (1985) found that egg weight, egg production and feed intake significantly decreased with $\beta$-mannan in laying hen diets. Previously published literature demonstrated that $\beta$-mannan enzyme is capable of improving the innate immunity and promoting a nonproductive energy draining response of the innate immune system (Zhang \& Tizzard, 1996; Duncan et al., 2002). This resulted in an increase in monocytes and macrophages proliferation and increased the production of cytokine. On the other side, many researchers found the positive impact of enzymatic degradation of $\beta$-mannan via supplementation of $\beta$-mannanase to diets of broiler chickens (Lee et al., 2003; Jackson et al., 2004), laying hens (Wu et al., 2005) and turkey birds (Odetallah et al., 2002). Jackson et al., (2003) reported that performance of birds experimentally inoculated with Clostridium perfringins and Eimeria spp. improved with the supplementation of $\beta$-mannanase. Despite the popularity of soybean meal in poultry feed, the content of $\beta$-mannan of this feedstuff has gained scant attention. This review paper compiles the updated information about $\beta$-mannanase, sheds light on the useful application as a feed additive on a commercial level in the poultry feed industry and explores the underlying mechanisms of action of Hemicell ${ }^{\circledR}$ (B-mannanase) on growth performance, metabolism, nutrient digestibility and health of poultry birds. Furthermore, research in depth on a molecular level is needed to expand the knowledge regarding the application of this important enzyme on a commercial level in the poultry feed industry.

\section{The anti-nutritive factors (ß-mannan) and its content in different feedstuffs}

Several anti-nutritive factors are used to prevent the nutrient utilization in avian species such as hemicelluloses, xylan, arabinan, galactan and mannan (Dhawan \& Kaur, 2007). Among them, mannan as a hemicellulosic polysaccharide is most abundant in nature after xylan (McCleary, 1986). The mannanases are being considered the second most important enzyme after xylanases, for hemicelluloses hydrolysis as described by Chauhan et al. (2012). The B-mannan is a highly anti-nutritional agent in poultry feeds (Odetallah et al., 2002). The contents of B-mannan in common feed ingredients for poultry are illustrated in Fig. 1. The B-mannan is always found in palm kernel meal, soybean meal, sesame meal, guar meal and copra meal (Dhawan \& Kaur, 2007). Guar meal and guar gum also have high concentrations of $\beta$-mannan (Rogel \& Vohra, 1983). The $\beta$-mannan content in soybean meal has an average galactose: mannose ratio between 1 and 1.8 which is similar to the guar gum i.e. 1 and 1.7 (Whistler \& Saarnio, 1957). Whistler \& Saarnio, (1957) demonstrated the galactomannan of soybean hulls in the 1950s. Another study confirmed that maximum mannan content was found in the NSP fractions (Dierick, 1989). The certain minor mixed linked mannans are also present in the fraction of soy protein as the major $\mathrm{N}$-linked carbohydrate of $\beta$-conglycinin (7S), a glycoprotein (Koshiyama, 1966; Kimura et al., 1997).

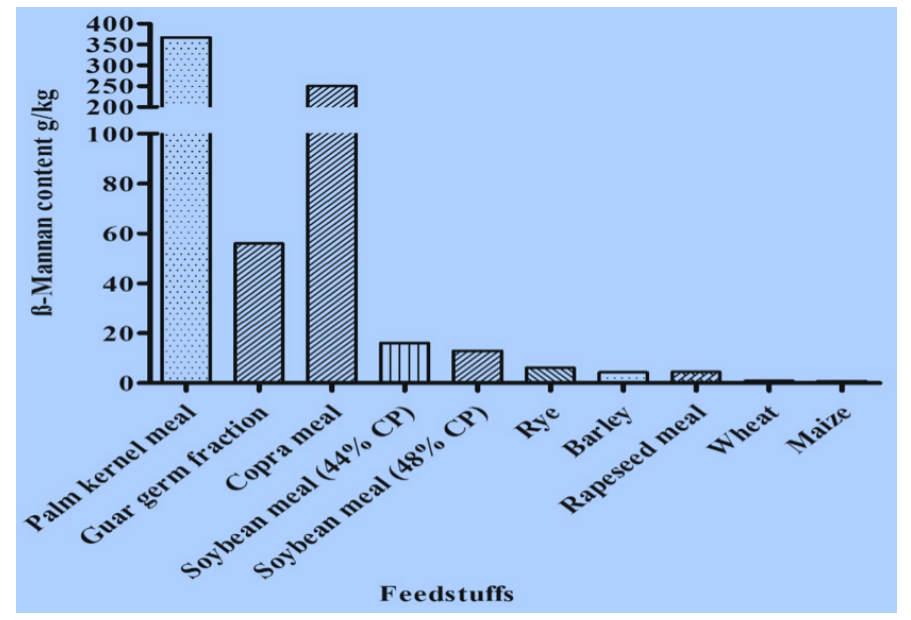

Figure 1 - The $\beta$-mannan contents $\mathrm{g} / \mathrm{kg}$ in different feedstuffs used for poultry nutrition.

\section{Different modes of action of $\beta$-mannanase}

The enzyme supplementation to diets reduces the viscosity of the intestinal ingesta and causes harmful impacts accompanied by elevated viscosity in the contents of the intestine (Almirall et al., 1995). The 
$\beta$-mannans naturally occurring in guar meal at 60 to $80 \mathrm{~g} / \mathrm{kg}$ bind large water amounts, which in turn increases the fluid viscosity of digestive tracts of animals (Danicke et al., 2000). The increases in viscosity can decrease water and glucose absorption as illustrated by Rainbird et al., (1984), consequently depressing growth performance and feed conversion ratio. The

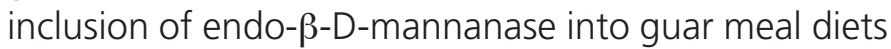
lowered viscosity of intestinal digesta and improved feed efficiency and growth performance (Lee et al., 2003). Moreover, Karimi \& Zhandi (2014) stated that feeding of $\beta$-glucanase and $\beta$-mannanase enzymesupplemented diet in graded levels of energy can modify some morphological traits of the gastrointestinal tract. The diet supplemented with $\beta$-mannanase may lead to improve the resistance against pathogenic bacteria such as Salmonella enteritidis (Gutierrez et al., 2008). $\beta$-mannanase's mechanism of action is by the hydrolysis of $\beta-1,4$-glycosidic linkages in $\beta$-mannans Fig. 2, (Ooi \& Kikuchi, 1995). The enzyme cleaves at random inside the 1, 4- $\beta$-D-mannan key chains of galactoglucomannan, galactomannan, and mannan (McCleary, 1986).

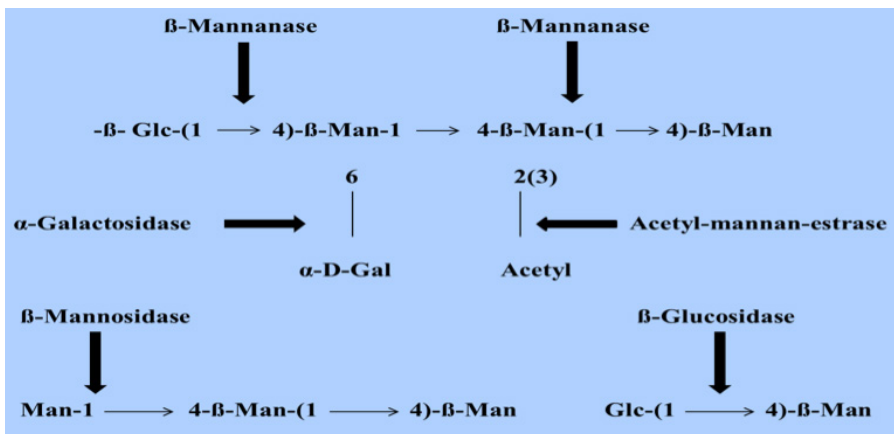

Figure 2 - Flow diagram about the enzymatic hydrolysis of galactoglucomannan (Glc=glucose; Man=mannose; Gal=galactose) (Puls \& Schuseil, 1993).

Another essential $\beta$-mannanase's mode of action is to reduce $\beta$-mannan levels in the gut, which may lead to a depression in the stimulation of innate immunity Fig. 3, (Jackson et al., 2004). Stimulation of the innate immunity occurs due to the absorption of $\beta$-mannan from the intestinal content and thereby improves the proliferation of monocytes and macrophages as well as resultant cytokine production. There are many other mechanisms which can explain the beneficial impacts of B-mannanase regarding nutrient digestibility and performance in poultry birds. These modes of action could be categorized as given below: (Shastak et al., 2015)

1) Impact on the viscosity of intestinal digesta

2) Release of some sugars such as D-mannose as a source of energy
3) Inhibition of pathogenic bacteria proliferation in the gut

4) Impact on immune response and release of bound nutrients.

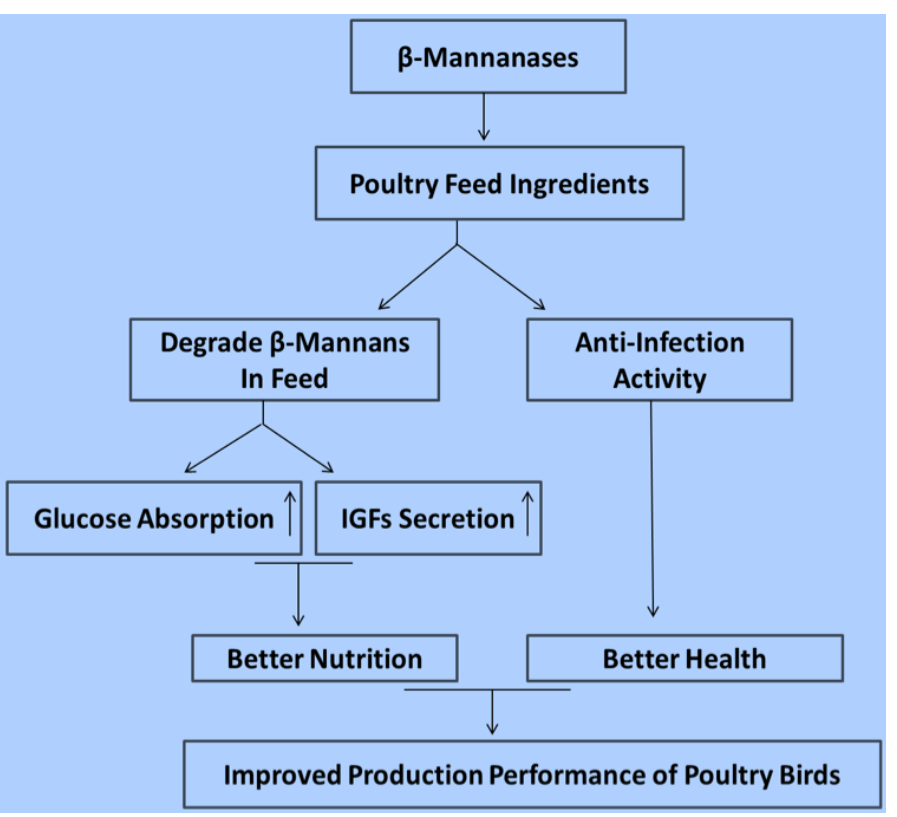

Figure 3 - Mode of action of $\beta$-mannanases.

\section{Impact on the viscosity of intestinal digesta}

The leguminous plants can be used as imbibing substances during the early period of germination, taking up water at high levels for spreading around the embryo as reported by Buckeridge et al., (2000). High molecular weight soluble copra and guar galactomannans could be dissolved in the gut forming high viscosity of intestinal digesta like other soluble B-glucans and arabinoxylans. Because of the high viscosity of intestinal digesta, galactomannans can have deleterious impacts on digestibility. This undesirable effect could be eliminated by using dietary supplementation of B-mannanase (Jackson et al., 2004). The supplementation of feed ingredients having a high amount of copra meal or guar meal (water-soluble galactomannan) may increase the viscosity of intestinal digesta in birds. Normally birds need a large amount of drinking water to keep the best mixing of intestinal substrates with enzymes. In research by Daskiran et al., (2004), supplementation of B-mannanase reduced the consumption of water per feed unit consumed in broiler chickens. In another study, chickens fed diets (corn soybean and copra meal) enriched with B-mannanase statistically enhanced protein, lipid and metabolizable energy utilization (Sundu et al., 2006, 2007). Results indicated that B-mannanase supplementation enhances the hydrolysis of copra meal which leads to upregulate 
the nutrient utilization and flow of intestinal digesta. Therefore, using B-mannanase to reduce the viscosity of the diets containing copra meal is similar to using xylanases in the diets containing wheat as mentioned by Dhawan \& Kaur (2007).

\section{Release of some sugars such as D-mannose as a source of energy}

Enzymes like $\beta$-mannosidase, $\alpha$-galactosidase and ß-mannanase are needed for $\beta$-mannans complete decomposition. The B-mannanase alone liberates short ß-1,4-manno-oligomers like mannotriose, mannotetraose, and mannobiose which can be hydrolyzed by B-mannosidases to mannose (Chauhan et al., 2012). Jackson et al. (2004) stated that positive impact of B-mannanase on the production of birds fed corn-soya meal diets could not be simply explained via making B-mannan available as a source of energy because the content of B-mannan in this diet is only $0.4 \%$ to $0.7 \%$. In addition, only a part of the absorbed D-mannose can be metabolized in birds (Duran et al., 2004). This means that the mode of action of B-mannanase could not itself provide extra energy to the poultry birds.

\section{Inhibition of pathogenic bacteria proliferation in the gut}

It is possible that B-1-4-mannan-rich feeds are pre-treated enzymatically and enriched with B-1-4MOS (manno-oligosaccharides) before fed to the poultry birds. In in vivo study by Agunos et al. (2007), MOS supplemented chicken feeds reduced caecal colonization Salmonella enteric in layer and broiler chickens (Shastak et al., 2015). In another study, regarding broilers, the addition of 20\% B-mannanase to treated copra meal diets reduced the population of Salmonella and Escherichia coli in excreta in comparison with non-enzymatic treated copra meal group (Khanongnuch et al., 2006). As reported by Jackson et al. (2003) and Latorre et al., (2015), B-mannanase found microbial modulating action in broiler chickens fed on corn-soya diets and challenged with Clostridium perfringens and Eimeria. B-mannanase reduced the severity of Eimeria and Clostridium infection verified by significant boost body weight gain and depression in some lesions in the intestine in comparison with the enzyme-free diet (Table 1).

Table 1 - Effect of infection, B-mannanase and medication on production performance of broilers from 8 to $21 \mathrm{~d}$ of age.

\begin{tabular}{|c|c|c|c|c|c|c|c|}
\hline Treatment & Infection ${ }^{1}$ & ß-annanase & Medication² & $B W G(g)$ & $\mathrm{FCR}(\mathrm{g} / \mathrm{g})$ & $\begin{array}{c}\text { Lesion score } \\
\text { upper }^{3}\end{array}$ & $\begin{array}{c}\text { Lesion score }(d \text { 14) } \\
\text { Lower }^{4}\end{array}$ \\
\hline 1 & - & - & + & $540^{a}$ & $1.45^{c}$ & $0.0^{c}$ & $0.0^{c}$ \\
\hline 2 & - & + & + & $548^{a}$ & $1.42^{c}$ & $0.0^{c}$ & $0.0^{c}$ \\
\hline 3 & + & - & - & $429^{d}$ & $1.70^{a}$ & $1.38^{a}$ & $1.56^{a}$ \\
\hline 4 & + & + & - & $490^{c}$ & $1.54^{b}$ & $1.16^{b}$ & $1.44^{a}$ \\
\hline 5 & + & - & + & $522^{b}$ & $1.45^{c}$ & $1.03^{b}$ & $0.88^{b}$ \\
\hline SEM & & & & 5.9 & 0.025 & 0.069 & 0.09 \\
\hline
\end{tabular}

a-d: Means within columns without common superscripts are significantly different $(p<0.05)$. 1: Orally inoculated with $\mathrm{E}$. acervulina and $\mathrm{E}$. maxima on day 7. On days 11 , 12 and 13 , birds were given broth cultures of C. perfingens. 2: Salinomycin (60g/ton) and bacitracin methylene disalicilate (50g/ton). 3: Area most affected by E. acervulina. 4: Area most affected by E. maxima. BWG: body weight gain. FCR: Feed conversion ratio. SEM: standard error of mean. Source: (Jackson et al., 2003).

\section{Impact on immune response and release of bound nutrients}

B-mannan has a molecular structure similar to some pathogens, which may trigger immune stimulation. Acemannan (B-1,4-acetylated mannan) induced the activation of macrophages via increasing the nitric oxide synthase level at transcription level as reported by Ramamoorthy et al. (1996). Karaca et al. (1995) reported that nitric oxide acts as a cytostatic effector in the removal of viral replication and is proposed to be toxic for tumor cells (Karupiah et al., 1993). The response of this complex to B-mannan containing compounds could lead to losses in dietary energy utilization. Supplementation of B-mannanase improved the utilization of dietary energy in cornsoya diet in broiler chickens (Li et al., 2010) as well as layers (Wu et al., 2005). Impacts of Hemicell ${ }^{\circledast}$ (B-mannanase) on the utilization of energy was partial because of the declined immune challenge which caused by B-mannan in rations, allowing more energy for production purposes (Li et al., 2010). The authors also found that B-mannanase mitigates the inhibitory impacts on digestive enzymes and thereby enhances the nutrient digestibility and reduces nutrient excretions. The aforementioned impact was assured by lower weights of the immune organs like bursa, thymus, and spleen; in addition to a lower concentration of serum IgG and IgM due to B-mannanase supplementation to broiler diets. Dale et al., (2008) stated reduced plasma concentrations of the acute phase protein indicating less immune function through removing soybean or through adding B-mannanase to broiler 
rations. Ferreira et al., (2016) studied the impact of $\beta$-mannanase addition to broiler diets on the growth, feed utilization, metabolizable energy, amino acid digestibility, and immune parameters and they found that immune response, energy values and growth were improved with $\beta$-mannanase-supplemented diets.

\section{The importance of enzymes especially B-mannanase in poultry feeds}

Poultry nutritionists are constantly attempting to enhance production performance of avian species, which are necessary for successful farming. In the last two decades several strategies were applied to uplift the commercial poultry production such as introduce environmentally control forming, improve feed formulation (Saeed et al., 2019; Saeed et al., 2018 a, b; Yatao et al., 2018), application of probiotics (Sun et al., 2016) and the use of herbal medicinal plants as an alternative source of antibiotics. The dietary enzymes are biologically active proteins that facilitate the breakdown of complicated nutrients into smaller molecules for further digestion and absorption (Thacker, 2013). There are large numbers of enzymes that are derived from microbes like fungi and bacteria via fermentation and have been used in poultry and their benefits in improving feed efficiency and growth. There are different classes of enzymes that are commonly employed in poultry diets including phytase, carbohydrases ( $\beta$-mannanase, xylanase, $\alpha$-galactosidase, cellulase, pectinase, and $\alpha$-amylase), and proteases as well. The biological activities of various in-feed enzymes in promoting the growth and improving the feed efficiency in poultry are well reported (Bedford \& Schulze, 1998; Choct, 2007).

It is now accepted that commercial enzymes play an important role in reducing anti-nutritional factors that exist in plant-based feed ingredients like phytic acid, NSP and cell-wall complex. The improved growth of poultry due to enzyme supplementation thus has been linked to an increase in the digestibility and absorption of nutrients (Verstegen \& Williams, 2002; Rebolé et al., 2010). The feed enzymes are considered as good potential as antibiotic alternatives to improve performance in poultry. Various meta-analyses studies conducted corroborate these benefits in birds upon supplementation of the enzyme (Rebole et al., 2010).

The Hemicell enzyme is well known as a fermentation product of Bacillus lentus. It contains high contents of B-mannanase that degrade -mannan in poultry ration. The B-mannanase has been shown to enhance feed efficiency of broiler chickens (Ward \& Fodge, 1996).
The guar and copra meals have also been reported to improve utilization with bacterial mannanase treatment (Patel \& McGinnis, 1985). Low-energy broiler chicken diets supplemented with B-mannanase revealed a better performance than broilers fed high-energy diets without enzyme (McNaughton et al., 1998). Supplementation of $\beta$-mannanase at the level of 200 and 400 ppm in poultry diet has positively improved blood glucose and anabolic hormone homeostasis, FCR, digestible energy, and digestible amino acids (Caldas et al., 2018). Recently, the published study demonstrated that $\beta$-mannanase supplemented at the level of ( 200 or $400 /$ ton) improved the ileal digestible energy (IDE), reduced intestinal viscosity, and improved growth performance of broiler chicken (Latham et al., 2017).

The findings from several researchers have shown increased utilization of nutrients in low $\beta$-mannans corn-soybean diets and other feed ingredients like copra and guar meal which are rich in mannan as a response to Hemicell supplementation. According to (Torki \& Chegeni, 2007), Hemicell supplementation to diets enriched with canola meal enhanced feed consumption, weight gain, and feed conversion ratio; however, the only improvement in body weight in comparison with canola meal diet with no Hemicell was statistically significant. The broiler chickens offered diets with Hemicell statistically increased the serum level of IgM of broilers at 3 and 6 wk-old. It was shown that Hemicell may improve immune functions and growth performance of broilers (Zou et al., 2006; Table 2 and 3). Rehman et al. (2013) found that $\beta$-mannanase supplementation in a low energy diet had a beneficial effect on the body weight, feed conversion ratio. Furthermore, Mussini et al. (2011) conducted a dosage response study with different levels of $\beta$ mannanase (CTCzyme) 0, 0.025\%, 0.05\% (recommended level) and $0.1 \%$ and observed that gross energy of excreta decreased with increasing enzyme level, demonstrating better nitrogen utilization by the birds. $\beta$-mannanase improves morphological status in the gut and immunological status in plasma in broiler chicks (Christine et al., 2002 and Mehri et

Table 2 - Results of different trials that represent the effect of $\beta$-mannanase on performance parameters.

\begin{tabular}{lccc}
\hline Treatments & Feed consumption & Weight gain & FCR \\
\hline Enzyme Hemicell , \% & & & \\
0 & 74.60 & $74.60^{\mathrm{a}}$ & $1.720^{\mathrm{a}}$ \\
0.025 & 74.61 & $44.30^{\mathrm{b}}$ & $1.684^{\mathrm{b}}$ \\
0.05 & 73.80 & $45.07^{\mathrm{b}}$ & $1.637^{\mathrm{c}}$ \\
0.075 & 75.91 & $44.44^{\mathrm{b}}$ & $1.710^{\mathrm{a}}$ \\
\hline
\end{tabular}

a, $\mathbf{b}, c:$ means in the same column sharing different superscripts differ significantly $(p<0.05)$, FCR: Feed conversion ratio. Source: (Zou et al., 2006). 
Table 3 - $\beta$-Mannanase enzyme for hemicellulose and their various sources and functions.

\begin{tabular}{llll}
\hline Organism & Substrate & Function & Probable results \\
\hline $\begin{array}{l}\text { Aspergillus niger, var. Bacillus } \\
\text { lentus }\end{array}$ & $\begin{array}{l}\text { Cereals and legumes } \\
\text { Bacillus subtitis }\end{array}$ & $\begin{array}{l}\text { Hydrolyzes b-mannans, } \\
\text { (e.g. Guar meal) } \\
\text { Trichoderma longibrachiatum }\end{array}$ & $\begin{array}{l}\text { Decreased anti-nutritive effects of } \beta \text {-mannans by reducing } \\
\text { digesta viscosity; increased } \beta \text {-mannans digestibility in feed, } \\
\text { production of oligosaccharides and ultimately improved value of } \\
\text { feed (energy). Also decreased problem of sticky dropping. }\end{array}$ \\
\hline
\end{tabular}

al., 2010), this may lead to the improved health status of birds. In another study, the supplementation of endo- $\beta$-D-mannanase (known as Hemicell ${ }^{\circledR}$ ), which is commercially available to guar meal based diets, promoted the growth of broilers (Daskiran et al., 2004). Broilers supplemented with B-mannanase in cornsoybean meal-based diets also increased daily weight gain of broiler chickens (Jackson et al., 2005; Zou et al., 2006). The better production performance may be associated with more energy availability by enzyme addition, since it minimizes the viscosity of the intestine by acting on the NSPs, allowing for better absorption of nutrient, thereby favoring higher body weight gain. In the study of Zangiabadi et al. (2010) broiler chickens fed on soybean or whole soy bean diets and added with $\beta$-mannanase at $350 \mathrm{~g} / \mathrm{kg}$ revealed beneficial effects on performance and immunity. El-Masry et al. (2017) pointed out that guar meal could be used in broiler diets at $5 \%$ with $\beta$-mannanase enzyme without negative impacts on the growth rate, feed efficiency and blood parameters.

\section{CONCLUSION}

The Hemicell commercial enzyme products with B-mannanase activity is a unique enzyme that can hydrolyze $\beta$-mannan, an anti-nutritional fiber in avian diets. Diet supplemented with $\beta$-mannanase may increase the population of intestinal beneficial bacteria, increase the digestibility of mannan, enhance the immunity, suppresses the growth of harmful bacteria, enhance the digestion and absorption of nutrients in the intestinal tract and reduce the environmental pollution by reducing ammonia emission. The promising effects of $\beta$-mannanase should be applied on a commercial level in the poultry feed industry. In addition, understanding the mechanisms which B-mannanase supplementation uses to affect growth performance, metabolism, digestibility and birds' health is essential for broadening and optimizing the use of this enzyme on a commercial scale in the poultry feed industry.

\section{CONFLICT OF INTERESTS}

The authors declare they have no conflict of interest.

\section{ACKNOWLEDGMENT}

The author is very thankful to the Department of Poultry science, Cholistan University of Veterinary and Animal Sciences Bahawalpur 63100, Pakistan.

\section{REFERENCES}

Agunos A, lbuki M, Yokomizo F, Mine Y. Effect of dietary beta1-4 mannobiose in the prevention of Salmonella enteritidis infection in broilers. Bristish Poultry Science 2007;48:331-341.

Alagawany M, Attia A. Effects of feeding sugar beet pulp and Avizyme supplementation on performance, egg quality, nutrient digestion and nitrogen balance of laying Japanese quail. Avian Biology Research 2015;8:79-88

Alagawany M, Attia Al, Ibrahim ZA, Mahmoud RA, El-Sayed SA. The effectiveness of dietary sunflower meal and exogenous enzyme on growth, digestive enzymes, carcass traits, and blood chemistry of broilers. Environmental Science and Pollution Research 2017;24:1231912327.

Almirall M, Francesch M, Perezvendrell AM, Brufau J, Estevegarcia E. The differences in intestinal viscosity produced by barley and beta-glucanase alter digesta enzyme-activities and ileal nutrient digestibilities more in broiler chicks than in cocks. The Journal of Nutrition 1995;125:947955.

Anderson JO, Warnick RE. Value of enzyme supplements in rations containing certain legume seed meals or gums. Poultry Science 1964;43:1091.

Bedford M, Schulze H. Exogenous enzymes for pigs and poultry. Nutrition Research Revivews 1998;11:91-114.

Buckeridge MS, Pessoa dos Santos H, Tiné MAS. Mobilisation of storage cell wall polysaccharides in seeds. Plant Physiology and Biochemistry 2000;38:141-156.

Caldas JV, Vignale K, Boonsinchai N, Wang J, Putsakum M, England JA, et al. The effect of $\beta$-mannanase on nutrient utilization and blood parameters in chicks fed diets containing soybean meal and guar gum. Poultry Science 2018;97(8):2807-2817.

Chauhan PS, Puri N, Sharma P, Gupta N. Mannanases: microbial sources, production, properties and potential biotechnological applications. Applied Microbiology and Biotechnology 2012;93:1817-1830.

Choct M. Enzymes for the feed industry: past, present and future. World's Poultry Science Journal 2007;62:5-16.

Choct M. Soluble non-starch polysaccharides affect net utilisation of energy by chickens Recent Advances in Animal Nutrition in Australia 1999;12:31-36.

Christine JG, Duncan CJG, Pasco DS, Pugh N. Ross SA. Isolation of a galactomannan that enhances macrophage activation from the edible fungus Morchella esculenta. Journal of Agricultural and Food Chemistry 2002;50:5683-5685. 
Dale N, Anderson D, Hsiao H. Identification of an inflammatory compound for chicks in soybean meal. Poultry Science 2008;87:153. Supplement

Dänicke $\mathrm{S}$, Jeroch $\mathrm{H}$, Böttcher W, Simon O. Interactions between dietary fat type and enzyme supplementation in broiler diets with high pentosan contents: effects on precaecal and total tract digestibility of fatty acids, metabolizability of gross energy, digesta viscosity and weights of small intestine. Animal Feed Science and Technology 2000;84:279-294

Daskiran M, Teeter RG, Fodge D, Hsiao HY. An evaluation of endo- $\beta$-Dmannanase (Hemicell) effects on broiler performance and energy use in diets varying in $\beta$-mannan content. Poultry Science 2004;83:662-668.

Dhawan S, Kaur J. Microbial mannanases: an overview of production and applications. Critical Reviews in Biotechnology 2007;27:197-216.

Dierick NA. Biotechnology aids to improve feed and feed digestion: enzymes and fermentation. Archiv für Tierernährung 1989;39:241-261.

Duncan CJ, Pugh N, Pasco DS, Ross SA. Isolation of a galactomannan that enhances macrophage activation from the edible fungus Morchella esculenta. Journal of Agricultural and Food Chemistry 2002;50:56835685

Duran JM, Cano M, Peral MJ, Ilundain AA. D-mannose transport and metabolism in isolated enterocytes. Glycobiology 2004;14:495-500

El-Masry KN, Ragaa NM, Tony MA, El-Banna RA. Effect of dietary inclusion of guar meal with or without $\beta$-mannanase Supplementation on Broiler Performance and Immunity. Pakistan Journal of Nutrition 2017;16:341350.

Ferreira HC, Jr., Hannas MI, Albino LF, Rostagno HS, Neme R, Faria BD, et al. Effect of the addition of beta-mannanase on the performance, metabolizable energy, amino acid digestibility coefficients, and immune functions of broilers fed different nutritional levels. Poultry Science 2016:95:1848-1857.

Gutierrez O, Zhang C, Caldwell DJ, Carey JB, Cartwright AL, Bailey CA. Guar meal diets as an alternative approach to inducing molt and improving Salmonella enteritidis resistance in late-phase laying hens. Poultry Science 2008;87:536-540.

Jackson M, Anderson D, Hsiao H, Jin F, Mathis G. Effect of B-mannanase (Hemicell (R)) on performance and body weight uniformity in broiler chickens provided with corn-soybean meal diets and economic ramifications. Poultry Science 2005; 82-83.

Jackson ME, Anderson DM, Hsiao HY, Mathis GF, Fodge DW. Beneficial effect of beta-mannanase feed enzyme on performance of chicks challenged with Eimerla sp. and Clostridium perfringens. Avian Diseases 2003;47:759-763

Jackson ME, Geronian K, Knox A, McNab J, McCartney E. A dose-response study with the feed enzyme beta-mannanase in broilers provided with corn-soybean meal based diets in the absence of antibiotic growth promoters. Poultry Science 2004;83:1992-1996.

Karaca K, Sharma JM, Nordgren R. Nitric oxide production by chicken macrophages activated by Acemannan, a complex carbohydrate extracted from Aloe vera. International Journal of Immunopharmacology 1995;17:183-188.

Karimi $\mathrm{K}$, Zhandi M. The effect of $\beta$-mannanase and $\beta$-glucanase on small intestine morphology in male broilers fed diets containing various levels of metabolizable energy. Journal of Applied Animal Research 2015;43:324-329.

Karupiah G, Xie QW, Buller RM, Nathan C, Duarte C, MacMicking JD. Inhibition of viral replication by interferon-gamma-induced nitric oxide synthase. Science 1993;261:1445-1448.
Khanongnuch C, Sanguansook C, Lumyong S. Nutritive Quality of $\beta$-Mannanase Treated Copra Meal in Broiler Diets and Effectiveness on Some Fecal Bacteria. International Journal of Poultry Science 2006;5:1087-1091

Kimura Y, Ohno A, Takagi S. Structural analysis of N-glycans of storage glycoproteins in soybean (Glycine max. L) seed. Bioscience, Biotechnology, and Biochemistry 1997;61:1866-1871.

Koshiyama I. Carbohydrate component in 75 protein of soybean casein fraction. Agricultural and Biological Chemistry 1966;30:646-650.

Latham RE, Williams MP, Walters HG, Carter B, Lee JT. Efficacy of $\beta$-mannanase on broiler growth performance and energy utilization in the presence of increasing dietary galactomannan. Poultry Science 2017;97:549-556

Latorre JD, Hernandez-Velasco X, Kuttappan VA, Wolfenden RE, Vicente JL, Wolfenden AD, et al. Selection of Bacillus spp. for cellulase and xylanase production as direct-fed microbials to reduce digesta viscosity and Clostridium perfringens proliferation using an in vitro digestive model in different poultry diets. Frontiers in Veterinary Science 2015;2:1-8

Lee JT, Bailey CA, Cartwright AL. beta-Mannanase ameliorates viscosityassociated depression of growth in broiler chickens fed guar germ and hull fractions. Poultry Science 2003;82:1925-1931.

Li Y, Chen X, Chen Y, Li Z, Cao Y. Effects of $\beta$-mannanase expressed by Pichia pastoris in corn-soybean meal diets on broiler performance, nutrient digestibility, energy utilization and immunoglobulin levels. Animal Feed Science and Technology 2010;159:59-67.

Mccleary BV. Enzymatic modification of plant polysaccharides. International Journal of Biological Macromolecules 1986;8:349-354.

McNaughton J, Hsiao H, Anderson D, Fodge D. Corn/soy/fat diets for broilers, $\beta$-mannanase and improved feed conversion. Poultry Science 1998;77:153

Mehri M, Adibmoradi M, Samie A, Shivazad M. Effects of beta-Mannanase on broiler performance, gut morphology and immune system. The African Journal of Biotechnology 2010;9:6221-6228.

Mussini SC, Coto CA, Goodgame S, Lu C, Karimi AJ, Lee J, Waldroup PW. Effect of CTCzyme 8-Mannanase on broiler performance and dry matter output using corn-soybean meal based diets. International Journal of Poultry Science 2011;10(10):778-781.

Odetallah NH, Ferket PR, Grimes JL, McNaughton JL. Effect of mannanendo-1,4-beta-mannosidase on the growth performance of turkeys fed diets containing 44 and $48 \%$ crude protein soybean meal. Poultry Science 2002;81:1322-1331

Ooi T, Kikuchi D. Purification and some properties of beta-mannanase from Bacillus sp. World Journal of Microbiology \& Biotechnology 1995:11:310-314

Patel MB, McGinnis J. The effect of autoclaving and enzyme supplementation of guar meal on the performance of chicks and laying hens. Poultry Science 1985;64:1148-56.

Puls J, Schuseil J. Chemistry of hemicelluloses: relationship between hemicellulose structure and enzymes required for hydrolysis In: Coughlan MP, Hazlewood GP, editors. Hemicellulose and hemicellulases. London: Portland Press; 1993. p.1-27.

Rainbird AL, Low AG, Zebrowska T. Effect of guar gum on glucose and water absorption from isolated loops of jejunum in conscious growing pigs. British Journal of Nutrition 1984;52:489-498.

Ramamoorthy L, Kemp MC, Tizard IR. Acemannan, a beta-(1,4)-acetylated mannan, induces nitric oxide production in macrophage cell line RAW 264.7. Molecular Pharmacology 1996;50:878-84. 
Rebole A, Ortiz LT, Rodriguez ML, Alzueta C, Trevino J, Velasco S. Effects of inulin and enzyme complex, individually or in combination, on growth performance, intestinal microflora, cecal fermentation characteristics, and jejunal histomorphology in broiler chickens fed a wheat- and barley-based diet. Poultry Science 2010;89:276-86.

Rehman ZU, Aziz T, Bhatti SA, Ahmad G, Kamran J, Umar S, et alC. Effect of $\beta$-mannanase on the performance and digestibility of broilers. Asian Journal of Animal and Veterinary Advances 2013;11:393-398.

Rogel AM, Vohra P. Hypocholesterolemia and growth-depression in chicks fed guar gum and konjac mannan. Journal of Nutrition 1983;113:873-

Saeed M, Babazadeh D, Arain MA, Naveed M, Shah QA, Kamboh AA, et al. The use of chicoric acid from Echinacea purpurea as a feed additive in poultry nutrition. Worlds Poultry Science Journal 2018b;74:1-9.

Saeed M, Yatao X, Hassan FU, Arain MA, Abd El-Hack ME, Noreldin AE, et al. Influence of graded levels of I-theanine dietary supplementation on growth performance, carcass traits, meat quality, organs histomorphometry, blood chemistry and immune response of broiler chickens. International Journal of Molecular Sciences 2018a;19:462.

Saeed M, Yatao X, Tiantian Z, Qian R, Chao S. 16S ribosomal RNA sequencing reveals a modulation of intestinal microbiome and immune response by dietary L-theanine supplementation in broiler chickens. Poultry Science 2019;98:842-854.

Sambrook IE, Rainbird AL. The effect of guar gum and level and source of dietary fat on glucose tolerance in growing pigs. Bristish Journal Nutrition 1985:54:27-35.

Shastak Y, Ader P, Feuerstein D, Ruehle R, Matuschek M. B-Mannan and mannanase in poultry nutrition. World's Poultry Science Journal 2015;71:161-174.

Sun $Y$, Rajput IR, Arain MA, Li $Y$, Baloch DM. Oral administration of Saccharomyces boulardii alters duodenal morphology, enzymatic activity and cytokine production response in broiler chickens. Animal Science Journal 2016:88:1204-1211.

Sundu B, Kumar A, Dingle J. Palm kernel meal in broiler diets: effect on chicken performance and health. World's Poultry Science Journal 2007;62:316-325
Sundu B, Kumar A, Dingle J. Response of broiler chicks fed increasing levels of copra meal and enzymes. International Journal Poultry Science 2006;5:13-18.

Thacker PA. Alternatives to antibiotics as growth promoters for use in swine production: a review. Journal of Animal Science and Biotechnology 2013:4:35.

Torki M, Chegeni A. Evaluation of dietary replacement of soybean meal by canola meal supplemented by $\beta$-mannanase (Hemicell) on performance of broiler chicks. Proceedings of the 16th European Symposium on Poultry Nutrition; 2007 Aug 26-30; Strasbourg. France. Netherlands: World Poultry Science Association; 2007. p.637-640

Verstegen MW, Williams BA. Alternatives to the use of antibiotics as growth promoters for monogastric animals. Animal Biotechnology 2002;13:113-127

Ward NE, Fodge D. Ingredients to counter antinutritional factors: soybeanbased feeds need enzymes too. Feed Management 1996;47(10):13-18.

Whistler RL, Saarnio J. Galactomannan from Soy Bean Hulls. Journal of the American Chemical Society 1957;79:6055-6057.

Wu G, Bryant MM, Voitle RA, Roland DA, Sr. Effects of beta-mannanase in corn-soy diets on commercial leghorns in second-cycle hens. Poultry Science 2005:84:894-897

Yatao X, Saeed M, Kamboh AA, Arain MA, Ahmad F, Suheryani I, ElHack Ma, et al. The potentially beneficial effects of supplementation with hesperidin in poultry diets. World's Poultry Science Journal 2018:74:265-276

Zangiabadi $\mathrm{H}$, Torki $\mathrm{M}$. The effect of a beta-mannanase-based enzyme on growth performance and humoral immune response of broiler chickens fed diets containing graded levels of whole dates. Tropical Animal Health and Production 2010:42:1209-1217.

Zhang L, Tizard IR. Activation of a mouse macrophage cell line by acemannan: the major carbohydrate fraction from Aloe vera gel. Immunopharmacology 1996;35:119-28.

Zou XT, Qiao XJ, Xu ZR. Effect of beta-mannanase (Hemicell) on growth performance and immunity of broilers. Poultry Science 2006;85:21762179 